\section{Unsettling Relations: The University as a Site of Feminist Struggles}

Himani Bannerji, Linda Carty, Kari Delhi, Susan Heald and Kate McKenna

Toronto: Women's Press 1991

ISBN0 $889611602 £ 6.95 \mathrm{Pbk}$

\section{Unsettling Relations: The University} as a Site of Feminist Struggles is a collection of challenging and readable essays by five women, each of whom is involved in feminist politics and academic teaching/research. As its title suggests, the book is concerned with the university as a set of social relations which are involved in the production of power and privilege, together with feminist struggles to resist and change them. Framed in this general way, the book is located intellectually within the now quite long history of feminist critique of the academy as a maledominated, liberal and middle-class preserve. Not surprisingly, therefore, some important parts of its conceptual framework are drawn from previously well-known feminist work - particularly that of the feminist sociologist Dorothy Smith. Two features are worth noting here: one is the notion that academic knowledge production is always inscribed within social and cultural relations of ruling. The second is the conviction that authentic (rather than simply 'academic') knowledge is intimately connected with - although not a direct reflection of - our bodily, sensuous and practical experiences in daily life.

Where the book is quite distinctive is in the sustained, detailed and critical attention it pays to the powers and privileges which are to be found, and which must be challenged, in the social relations of feminist pedagogy and research. Here, the authors' starting point is in more recent critiques of the way that many women have been socially positioned as 'other' and as 'different' by a white, middle-class, heterosexual and able-bodied hegemony in feminist knowledge. As one of the contributors to the volume has written previously, such practices have produced 'silences or absences, creating gaps and fissures through which non-white women, for example, disappear from the social surface' (Bannerji, 1987:11). A further aim of Unsettling Relations, therefore, is to write the experiences of many previously neglected women into analyses of feminist academic relations. In order to achieve this, the introduction describes how each contributor to the volume has been enjoined to centre 'race' and class as well as gender, and to reflexively include a history of her own personal experiences of social positioning, within her chapter.

Following a brief 'introduction' to the background and aims of the book, a number of the main themes are developed in the first chapter by Linda Carty. Her own experiences of racism in education are used to illustrate the history of black people's marginalization in academic knowledge including feminist theory, given the construction of whiteness as a 'neutral' reference point. Kari Delhi explores how her whiteness has positioned her in relations of power over other women, and argues that white middle-class women must resist the comforts and seductions of university as 'home'. The third chapter by Himani Bannerji poses the question of why feminist research and pedagogy has been unable to validate non-white women's experiences, subjectivities and direct agency. She then answers this question by providing a critical account of feminist epistemologies (essentialist, politics of difference and Marxist/ socialist), and by arguing for a 'reflexive and relational social analysis which incorporates in it a theory of agency and direct representation based on our experience' (p. 94). One important benefit of this approach is that it works out a political position 
within which racist social practices can be identified and challenged by all women 'without substitution, guilt and condescension' (p. 96).

The final two chapters are more centrally concerned with the subject positions of women as learner and teacher. Kate McKenna describes instances recorded in ethnographic field-work notes of her experiences on returning to university as a mature student of women's studies, to demonstrate how social relations and modes of (sometimes self-) regulation can limit feminist learning and knowing. Susan Heald's chapter brings the book to an end with an overview of liberal humanist and poststructuralist theories of subjectivity, together with a reflection on the various intersecting and often contradictory discourses which constructed a pathway for her own social development. She suggests that women in academic life need to learn how to protect themselves, by understanding how 'non-normalcy' makes participation difficult, and elaborates on this by referring to one of her chosen tactics of concealing her lesbian sexuality and difficulties with hearing in the classroom. However, she recognizes that deconstructing the otherwise apparently unitary category 'white women' is also vital, since comparisons across many dimensions of difference are necessary if we are fully to understand the way relations of oppression and domination are maintained.

This book deserves to be read widely. It is successful as an example of a collaboration between feminist teachers/researchers, addressing important and at times controversial issues coherently but without obliterating differences of views. A number of the contributors remark honestly how they experienced difficulties with writing in the personal (Linda Carty because she did not want to present a false picture of a 'personal debacle' (p. 33), and Kari Delhi because she doubted the motives of white feminists writing personal 'confessionals' (p. 51) and was wary of engaging in self-indulgence) comments which I found useful. Nevertheless, each writer does, at least to some degree, manage to reflexively incorporate the particularities of the social positioning of her own biography within wider social and political analyses of racism, dominance and subordination, and the production of marginality and otherness in academic life. Consequently it testifies to the possibility of transforming feminist research, by putting important political, ethical and epistemological principles into practice more fully.

If I had to express reservations, one would be that the authors have not reflected fully on the position, role and value of institutions of higher education and learning in the context of wider historical and contemporary political relations and change. As a white woman with a permanent academic position, I recognize that my own interests and privileges are implicated here. However, while it is important that feminist academicians reflect critically on our own social relations and practices, this must not be at the expense of devaluing - both personally and politically - our daily lives as teachers and researchers and the academic work that we do. Bannerji and her colleagues are correct to point out that we must be accountable to our political affiliations beyond the university in our academic work and relations. But equally, we must acknowledge, as feminist researchers, the complexity of the relationship between our politics and our teaching and research, which is bound up with the practical effectivity of meaningful symbols, words and ideas. Also, speaking personally, I have come to believe that we have a special responsibility as the incumbents of institutions of learning to speak out for the right to do intellectual work which can promise no direct practical or instrumental benefit. Active protection of this 
'privilege' is particularly important in many places at the present time, given widespread capitulation to the view that 'education' is no more than a training in skills that will prove useful in the production of markets, goods and wealth.

The latter point also leads me to resist, in part, the criticism many of the authors make of the way that feminist studies within the university may function as 'home'. I can agree that there is a need to undermine those social relationships which function as a bastion of middle-class privilege. I can also appreciate the well-chosen metaphor which alerts us that, together with the comforts offered by an academic 'home', such an environment can threaten to limit us through the imposition of obligations, conventions and ties. However, having entered university as a young, working-class woman, and later located myself within feminist studies (particularly as fashioned by 'standpoint science'), my experience is that I have needed the sense of security, confidence and (temporarily fixed) identity they have afforded me in my struggle to find a personal and politi- cal voice. I would, therefore, tend to agree with the suggestion in Susan Heald's chapter that it may be necessary to construct a new 'home', based upon changed and firmer foundations, to support the activities of feminist academic research.

This book could certainly be recommended as useful reading on postgraduate and even some undergraduate courses that are informed by the principles of feminist pedagogy and research. The compelling accounts of personal struggles with academic institutions and practices also make it a potentially useful resource for $\mathrm{Ph} . \mathrm{D}$. students, as a support through difficult times in their research. I shall recommend to my students that it is read alongside articles such as Angela MacRobbie's one on the politics of feminist research in Feminist Review No. 12.

\section{Karen Henwood}

\section{Reference}

BANNERJ H. (1987) Introducing Racism: Notes Towards an Anti-Racist Feminism Resources for Feminist Research/ Documentation sur la recherche femin. iste Vol 16, No. 1.

\section{Feminist Epistemologies}

\section{Edited by Linda Alcoff and Elizabeth Potter}

London: Routledge 1993

ISBN $041590451 X £ 12.99$ Pbk

ISBN0415904501£35.00 Hbk

You might say that the problems of feminist epistemology are the problems of a political project hoist by its own petard. It's one of the very basic tenets of feminism that propositions commonly presented as 'objective' knowledge are all too often highly value-laden assertions which both arise from and perpetuate situations of domination and oppression: this tenet has been seen to apply not just to assertions of 'knowledge' about the inferiority of women made by medical, scientific, academic and other establishments throughout history, but also, more recently, to 'knowledge' claims made by feminists themselves which have arisen from and perpetuated forms of domination within feminism and between women along axes of race, class, age, ability and difference. The epistemological problem which emerges from this long, fierce and often painful history now is: if, as feminism has claimed, assertions of 'knowledge' are so often both producers and guarantors of domination and power, how can feminism itself legitimately claim to be a site of 'knowledge' about the oppression of women or, indeed, about anything at all? And if feminism cannot make such a claim, how can it continue as a political project for the liberation of 